\title{
Nutrient retention behind a tropical mega-dam: a case study of the Sardar Sarovar Dam, India
}

\author{
Harish Gupta ${ }^{1}$ (1) S. Kiran Kumar Reddy ${ }^{2} \cdot$ Mounika Chiluka $^{3} \cdot$ Vamshikrishna Gandla $^{3}$
}

Received: 21 July 2020 / Accepted: 29 December 2020 / Published online: 7 January 2021

(C) The Author(s) 2021 OPEN

\begin{abstract}
In this study, we demonstrate the impact of the construction of a mega-dam on the nutrient export regime of a large tropical river into the Arabian Sea. Long-term (11 years) fortnight nutrient parameters, upstream and downstream to Sardar Sarovar (SS) Dam, were examined to determine the periodical change in nutrient fluxes from the Narmada River, India. During this 11-year period, the average discharge of the Narmada River upstream to Rajghat $\left(35.3 \mathrm{~km}^{3} \mathrm{year}^{-1}\right)$ was higher than that of downstream at Garudeshwar $\left(33.9 \mathrm{~km}^{3}\right.$ year $\left.^{-1}\right)$. However, during the same period, the suspended sediment load was reduced by 21 million tons (MT) from 37.9 MT at Rajghat to 16.7 MT at Garudeshwar. Similarly, mean concentrations of dissolved silica (DSi) reduced from 470 (upstream) to $214 \mu \mathrm{M}$ (downstream), dissolved inorganic phosphate (DIP) from 0.84 to $0.38 \mu \mathrm{M}$, and dissolved inorganic nitrogen (DIN) from 43 to $1.5 \mu \mathrm{M}$. It means that about $54 \%, 55 \%$, and $96 \%$ flux of DSi, DIP, and DIN retained behind the dam, respectively. The estimated denitrification rate $\left(80,000 \mathrm{~kg} \mathrm{~N} \mathrm{~km}^{-2} \mathrm{year}^{-1}\right)$ for the reservoir is significantly higher than $\mathrm{N}$ removal by lentic systems, globally. We hypothesize that processes such as biological uptake and denitrification under anoxic conditions could be a key reason for the significant loss of nutrients, particularly of DIN. Finally, we anticipated that a decline in DIN fluxes (by $1.13 \times 10^{9} \mathrm{~mol}^{-1} \mathrm{year}^{-1}$ ) from the Narmada River to the Arabian Sea might reduce the atmospheric $\mathrm{CO}_{2}$ fixation by $7.46 \times 10^{9} \mathrm{~mol}_{\text {year }}{ }^{-1}$.
\end{abstract}

Keywords Tropical river Dam reservoir $\cdot$ Nutrient sequestration $\cdot$ Molar ratios $\cdot \mathrm{CO}_{2}$ consumption $\cdot$ Arabian Sea

\section{Introduction}

Water is a crucial requirement to meet surging demands and secure year-round water supplies for irrigation, industries, and human settlements. Hence, the second half of the twentieth century witnessed the construction of thousands of dams per year worldwide. Downing et al. [18] estimated that there are at least 0.5 million impoundments with a reservoir area of $\geq 0.01 \mathrm{~km}^{2}$ globally, covering $>0.25$ million $\mathrm{km}^{2}$ of the earth's land surface. It includes about 58,000 large dams with a height of $\geq 15 \mathrm{~m}$ [37]. Currently, $8000 \mathrm{~km}^{3}$ of water is stored behind large reservoirs [72], globally. This transformation impacted rivers' natural flow patterns, water exchange among various reservoirs, and downstream transport of riverine load. Reservoirs have substantially impacted the riverine transfer of dissolved and particulate loads. On the global scale, rivers account for transporting about $90 \%$ of the dissolved and particulate matter fluxes from terrestrial environments to coastal regions [14]. A plethora of studies have documented sediment trapping behind dams; however, dams' influence on dissolved materials transport is poorly understood.

Human perturbations have greatly accelerated the flow of nutrients to the coastal ecosystems, which compelled Meybeck [50] to point out that anthropogenic supplies

$\triangle$ Harish Gupta, harishgupta78@osmania.ac.in; S. Kiran Kumar Reddy, skiran2888@gmail.com; Mounika Chiluka, mounikageo@gmail.com | ${ }^{1}$ Engineering Geology Division, Department of Civil Engineering, Osmania University, Hyderabad 50007, India. ${ }^{2}$ Hydrogeochemistry Division, CSIR-National Geophysical Research Institute, Hyderabad 50007, India. ${ }^{3}$ Department of Applied Geochemistry, Osmania University, Hyderabad 50007, India. 
now dominate the earlier controlled ecosystems by earth system drivers. It is evident by the fact that during the last century, the global riverine fluxes for nitrogen $(\mathrm{N})$ [22] and phosphorous (P) [49] doubled. Hence, since the beginning of the twentieth century, most of the focus has been on investigating the impact of increased $\mathrm{N}$ and $\mathrm{P}$ fluxes on primary productivity, phytoplankton blooms, and bottom water hypoxia in coastal regions. However, the situation is rapidly changing as several recent studies, i.e., Garnier et al. [24], Kelly [41], Teodoru and Wehrli [68], Leavitt et al. [44], Patoine et al. [57], Harrison et al. [32], Maavara et al. [49], Van Cappellen and Maavara [71], and Liu et al. [45] have investigated the role of human-made reservoirs on downstream transport of nutrients by rivers. In this context, $\mathrm{N}$ removal by terrestrial-aquatic systems has received significant attention, since numerous studies have shown that freshwater bodies constitute the foremost sink for $\mathrm{N}$ within watersheds. For example, Saunders and Kalff [63] estimated that on average, wetlands, lakes, and rivers retain $64 \%, 34 \%$, and $2 \%$, respectively, of the total $\mathrm{N}$ loading. In a global-scale modeling study, Harrison et al. [32] demonstrated that $\mathrm{N}$ removal behind dams varies from 0 to $99 \%$ and 0.04 to $68.5 \%$ in reservoirs located in temperate and tropical regions, respectively. Similarly, dams reduced the global riverine $P$ supply to coastal regions by $12 \%$ [49]. It implies that increased loading of $N$ and $P$ to coastal seas may have been compromised by rising numbers of dams [46]. Besides, studies proposed mechanism of nutrient removal in the reservoirs. Various studies quantified the relative importance of various processes resulting in removal of DIN (i.e., $[2,31])$, DIP $[49,76]$ and DSi $[21,35]$ in reservoirs and its impact on biogeochemical cycling [47]. It is important as riverine supply of nutrients, such as DIN, DIP, DSi and carbon (C) form basis for marine food webs. The riverine influx of nutrients, while linking continental and oceanic components of the global biogeochemical cycle, also regulates photosynthesis in the coastal areas. It is known that $\mathrm{N}$ limits the primary productivity in much of modern oceans $[19,23]$. However, recently Maavara et al. [46] suggested that worldwide, preferential removal of $P$ over $N$ in reservoirs increases $N: P$ ratios delivered to the ocean, raising the potential for $P$ limitation of coastal productivity. Hence, riverine inputs and the availability of nutrients that are supposed to control coastal ecosystems' productive function are changing. Damming of rivers impacts both absolute and relative nutrient loads and carbon fixation in the oceans through photosynthesis acts as a contemporary carbon sink, thereby subsidizing anthropogenically derived $\mathrm{CO}_{2}$ from the atmosphere. It implies that a change in downstream nutrient loads and ratios would imply the production and growth of phytoplankton and hence on carbon sequestration in the coastal seas.
In India, employment and the socioeconomic fate of rural communities primarily depend on agriculture. Population pressure and rapid development of the agricultural sector has been accompanied by the widespread application of fertilizers and pesticides. India is one of the largest consumers of synthetic nitrogen fertilizers $(\sim 17$ million tons (MT) $\mathrm{N}$ year ${ }^{-1}$ ) in the world [3]. It might have increased the riverine nutrient inputs to the coastal seas. To meet the growing demand for water for various purposes about 5264 large dams were constructed across the Indian landmass [55]. Most of these dams (4894) were constructed starting from 1951. Gupta et al. [29] estimated that due to dams' construction, the annual sediment load of the Indian peninsular rivers reduced from 342 to 83 MT. A vast number of global studies suggest that damming alters the riverine export of organic carbon and nutrients to the coastal seas the riverine export of organic carbon and nutrients to the coastal seas and influences the primary productivity in the downstream freshwater and saline waters. It is essential as recent studies $[5,52,53]$, have reported low nitrate concentration and absence of measurable oxygen from the hypolimnion in the Indian reservoirs and provided evidence of the formation of $\mathrm{CH}_{4}$ and $\mathrm{N}_{2} \mathrm{O}$. It motivated us to measure the changes in nutrient fluxes in Indian rivers and to evaluate its potential impact on downstream ecosystems. One of the main hurdles in establishing any local- or regional-scale influence of dams on nutrient transport is the scarcity of pre- and postdam long-term nutrient flux measurements. To take up this issue, the present study analyzes long-term data of water discharge, sediment flux, and dissolved nutrient concentrations of two specific locations from the Narmada basin, covering a mega-dam (Fig. 1). This paper's primary objective is to examine the impact of the dam on the downstream fluxes of dissolved inorganic nutrients. Based on the literature review, we attempt to propose the possible mechanism and implications of a change in nutrient fluxes on marginal productivity. Looking at the exact mechanism resulting in a decline of nutrients through experiments is out of the current study's scope due to logistic issues and administrative restrictions.

\section{Materials and methods}

\subsection{Study area}

The Narmada is a large west-flowing Indian peninsular river with a $1333 \mathrm{~km}$ long mainstream channel covering a catchment area of $92,672 \mathrm{~km}^{2}$. The basin area is primarily agricultural (57\%), followed by forest land (33\%). The climate of the basin is humid and tropical. Nearly $90 \%$ of $1100 \mathrm{~mm}$ rainfall is received during the five 


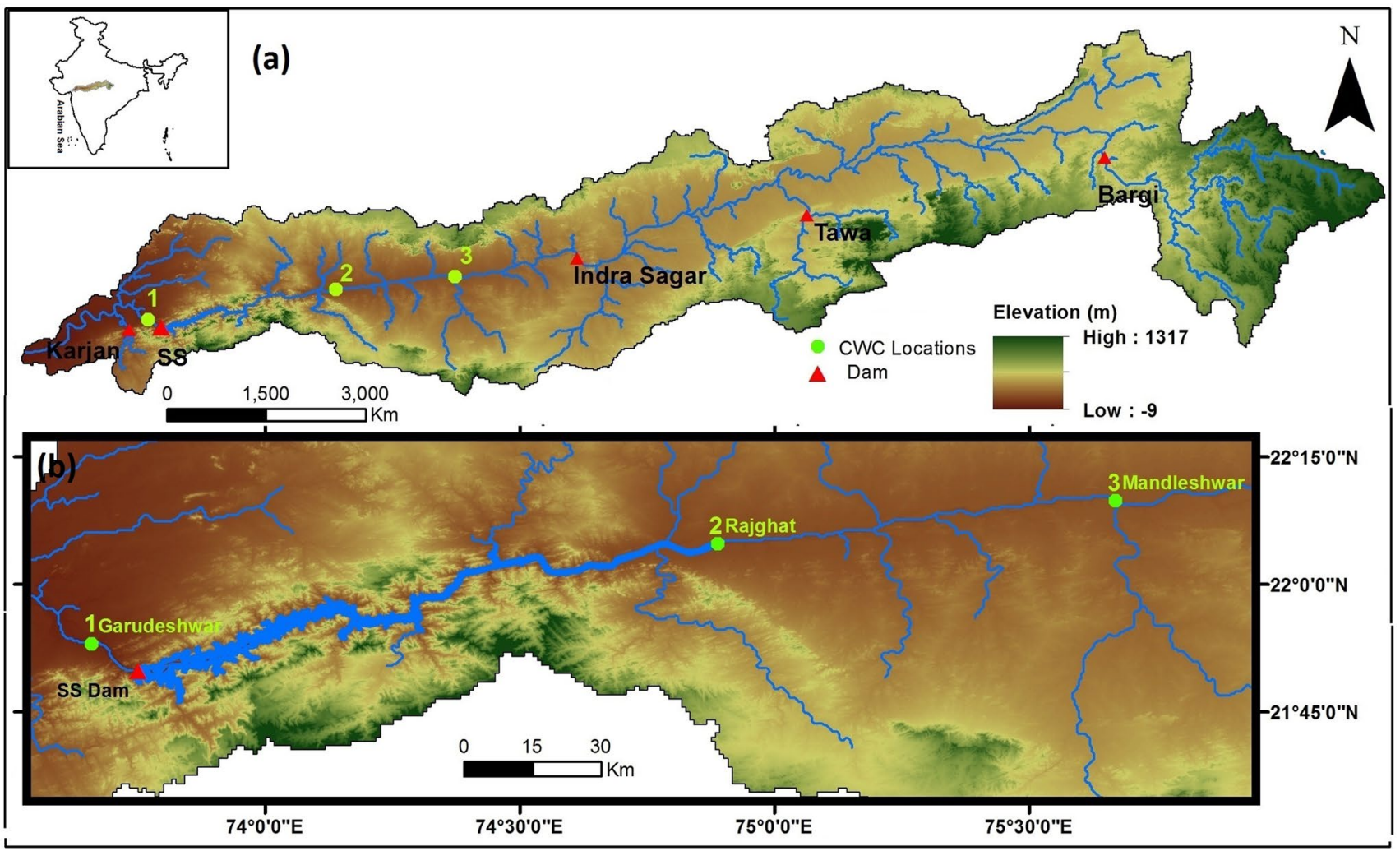

Fig. 1 Location maps of Narmada basin with Sardar Sarovar (SS) Dam and study sites Rajghat (upstream) and Garudeshwar (downstream). The foundation stone of the Sardar Sarovar Dam was laid

monsoon months between June and October. The monsoon season accounts for $70-92 \%$ of water discharge in the Narmada basin [27]. The surface water utilization in the Narmada basin was insignificant before India's independence (August 1947).

The Central Water Commission (CWC), Government of India is an apex government organization entrusted with responsibilities of monitoring Indian rivers (http:// www.cwc.nic.in/). In the Narmada basin, the CWC maintains twenty WQ monitoring stations, and ten of them are located on the Narmada mainstream, thus allowing a comparison of the downstream evolution of concentration and fluxes. Presently, the Narmada basin hosts five mega-dams and several large dams (Fig. 1a). Among the 30 major, 135 medium, and 3000 minor projects planned for irrigation and hydel power generation in the Narmada basin, the Sardar Sarovar (SS) Dam is the largest, followed by the Indira Sagar and the Bargi dams on the mainstream. The total storage capacity of the SS dam reservoir is $9.5 \mathrm{~km}^{3}$, and it covers a reservoir area of $375 \mathrm{~km}^{2}$. The maximum length (backwater spread) of the reservoir is $214 \mathrm{~km}$. It is estimated that about $138 \mathrm{~km}^{2}$ of prime forest land is submerged under the reservoir's backwater [40]. in 1961. The dam's construction began in 1987, and by 2000-2001, dam reached a height of $90 \mathrm{~m}$

\subsection{Approach and the source of data}

The SS dam's foundation stone was laid in 1961; World Bank financed the project in 1979. However, due to agitations and litigations, the construction of the project was stalled in between several times. The dam's construction began in 1987 and by 2000-2001 dam reached a height of $90 \mathrm{~m}$. Therefore, the period between 1990 and 2000 is selected to compare the changes in nutrient fluxes and ratios in this study. Rajghat $\left(22^{\circ} 4^{\prime} \mathrm{N}\right.$ and $\left.74^{\circ} 53^{\prime} \mathrm{E}\right)$ is located $175 \mathrm{~km}$ upstream from the dam site, whereas Garudeshwar $\left(21^{\circ} 53^{\prime} \mathrm{N}\right.$ and $\left.73^{\circ} 38^{\prime} \mathrm{E}\right)$ is located $8 \mathrm{~km}$ downstream of the dam site (Fig. 1b). The Narmada mainstream between Rajghat and Garudeshwar covered an area of $100 \mathrm{~km}^{2}$ (Fig. 1a) before the start of dam construction, and by 2000-2001, it was about $195 \mathrm{~km}^{2}$ (Fig. 1b). Except for Hathni $\left(0.30 \mathrm{~km}^{3}\right)$, no major tributary contributes between Rajghat and Garudeshwar; thus, it is assumed that Rajghat serves as an inlet and Garudeshwar as an outlet for this human-made lake. The SS dam is the last dam on the mainstream and hence regulates the flow of water, sediment, and dissolved loads to the Arabian Sea.

The water quality (WQ) data, annual water discharge, and sediment load used in this study were obtained from 
the CWC. The field monitoring stations of CWC measures water discharge and suspended sediments daily. Area-velocity method using a current meter was used to measure the water discharge at the gauging stations once every day. Water level or stage is measured every hour during the monsoon period and once a day during non-monsoon period. The suspended sediment concentrations are obtained by filtering known volumes of water samples through $0.45 \mu \mathrm{m}$ filter papers and weighing the difference in dry filter paper before filtration and after filtration $[26,27]$.

In contrast, the WQ parameters $(\mathrm{pH}$, temperature $(\mathrm{T})$, electric conductivity (EC), total dissolved solids (TDS), dissolved oxygen (DO) major ions, nutrients, i.e., nitrate, phosphate, and silicate) are analyzed fortnightly. The CWC has a well-established 'Water Quality Monitoring Network' consisting of monitors stations at 552 key locations covering all India's major river basins. A three-tier network of water quality monitoring stations has been implanted by CWC all over India [12]. Detailed sample collection methods and analytical techniques were described in CWC working manuals [13] and are summarized here. Water samples are collected at 0.6 times the depth from the surface without disturbing the bottom sediments, from the point across the river section having the maximum depth or maximum flow along the river's cross section. The samples are collected in clean and pre-rinsed plastic bottles of one-liter capacity, filled up to their full capacity without air bubbles. In situ measurements for parameters like in situ T, pH, color, odor, EC, TDS, and DO are done at the field laboratory (level I laboratory). The water samples thus collected are sent for analysis to the CWC divisional laboratory at Bhopal (level II laboratory) by a dedicated team to reach within $24 \mathrm{~h}$ of collection. In the level II laboratory, samples were filtered using $0.45 \mu \mathrm{m}$ cellulose acetate filters and stored in a refrigerator at $4{ }^{\circ} \mathrm{C}$ until further analysis. The UV spectrophotometer was used to measure the dissolved ammonium, nitrate, nitrite, phosphate, and silica [13]. Major ions analyzed using Atomic Absorption Spectrometer (AAS) and Colorimeter. A series of in-house standards are used for calibrations. Chemical data of the water samples analyzed by the CWC laboratory at Bhopal of the Narmada basin for the study period show NICB within $\pm 10 \%$ [28].

The output of nutrients at the monitoring station was estimated by combining instantaneous river discharge measurement $\left(\mathrm{m}^{3} \mathrm{~s}^{-1}\right)$ and concentrations $\left(\mathrm{mg} \mathrm{l}^{-1}\right)$, every fortnight. The instantaneous fluxes were used to calculate daily fluxes (tons per day) for all nutrient species, specified in this work. Such obtained fluxes for 24 days (twice every month) represent the entire annual hydrological regime. These discharge-weighted numbers were averaged and multiplied by the same year's annual discharge to estimate the annual flux (in MT) of the respective monitoring stations.

This study uses cumulative plots, double mass plot, and trend analysis to visualize the long-term change in water discharge, sediment loads, and nutrient fluxes. Linear regression and the Mann-Kendall Trend Test (M-K test) are used to analyze data collected over time for evaluating the trends in $\mathrm{Y}$ values [38]. Here, the terms DIN, DIP, and DSi denote dissolved inorganic nitrogen (including $\mathrm{NO}_{3}^{-}, \mathrm{NO}_{2}{ }^{-}, \mathrm{NH}_{4}{ }^{+}$), phosphate, and silica, respectively.

\section{Results and discussion}

\subsection{Sediment and dissolved load trapping behind the reservoir}

To evaluate the SS dam's impact on riverine material transport, we compared both locations for their annual water discharge, sediment fluxes, and dissolved nutrient loads. Following Walling [74], cumulative curves are used to provide an explicit depiction of pre- and post-dam changes in water and sediment fluxes. Annual water discharge (for 43 years), sediment load (for 27 years), and WQ (collected fortnightly, between June 1990 and May 2001) data of Rajghat and Garudeshwar stations used to construct the cumulative curve. Figure 2a shows that till the year 2000-2001, water discharge at Garudeshwar was slightly higher than that of Rajghat; after that, it plunged below the 1:1 line. However, since 1981-1982, a remarkable decline in the annual sediment load is recorded (Fig. 2a). Similarly, at an annual scale, dissolved load showed a significant decline in downstream flux (Fig. 2b).

Double mass plot (Fig. 3) -another tool frequently used to identify changes in the sediment response of a river [73] - suggests that both the water discharge and sediment load have responded to controls, identically. However, in contrast to Rajghat, the double mass plot for Garudeshwar shows notable declining trends. According to Jain et al. [38], rainfall patterns remain constant for the Narmada basin; therefore, the influence of climate change is ruled out. Therefore, downstream reduction in fluxes mainly sediments and dissolved loads, most likely reflect retention behind the SS dam. Our observations are following previous observations for the Narmada basin [26, 27]. Gupta et al. [29] estimated that over 30 years, the annual seaward sediment load of the Narmada River reduced by $95 \%$, which resulted in the deposition of 400 MT of sediment load in the SS reservoir. Gupta et al. [28] estimated that the SS reservoir retained more than $30 \%$ of chemically derived dissolved fluxes. 


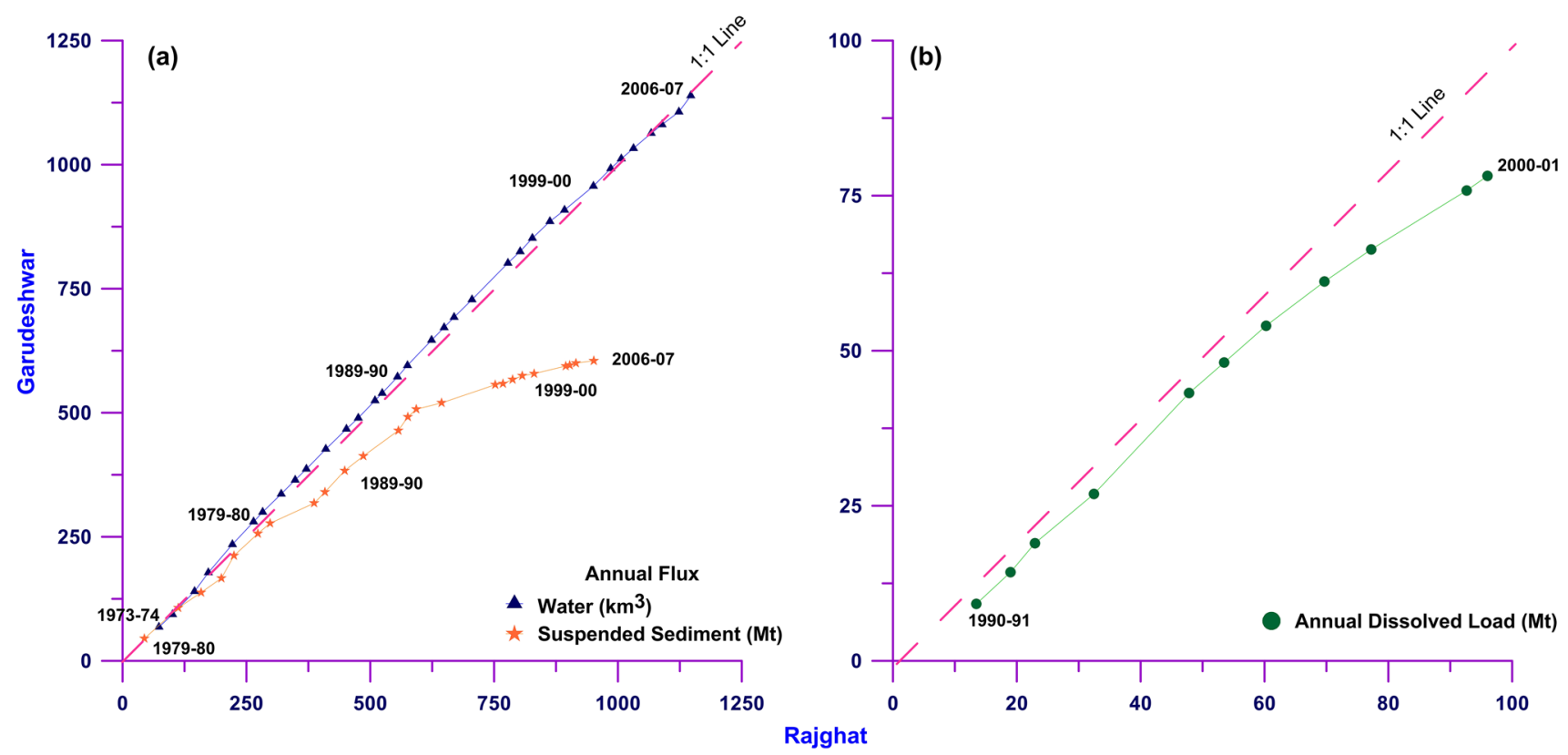

Fig. 2 Variations in the cumulative a water, sediment, and $\mathbf{b}$ dissolved fluxes for the Narmada River at upstream (Rajghat) and downstream (Garudeshwar) locations. A hypothetical 1:1 line (dashed line) has been drawn for comparison

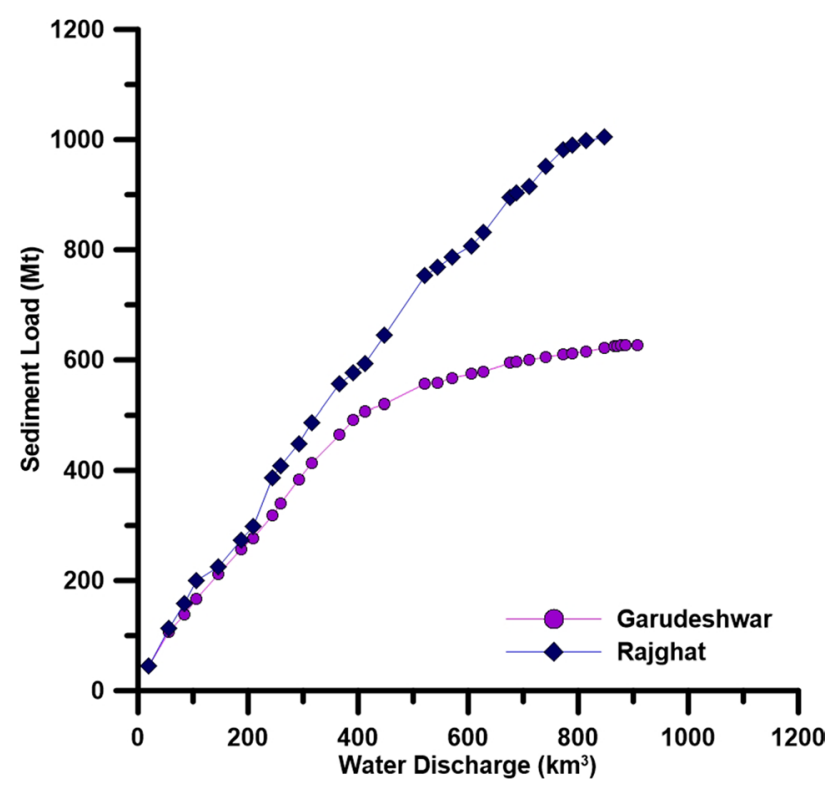

Fig. 3 Double mass plot illustrating the response of annual water discharge and sediment loads at Rajghat and Garudeshwar stations

\subsection{Trapping of inorganic nutrients behind the reservoir}

In order to assess the status of nutrient loading in the Narmada mainstream, 11 years of fortnight nutrient data of the Rajghat and the Garudeshwar sites were used for trend analysis. At the Rajghat, DIN and DIP concentrations show an insignificant increase, suggesting no significant changes in inputs over the study period. However, the DSi concentration trend analysis confirms a significant upward trend ( $p>0.001$ ) for Rajghat station. In stark contrast to Rajghat, at Garudeshwar, these variables not only showed declining trends, but concentrations also reduced markedly. However, the reduction in concentration is statistically significant only for DSi and DIN (Fig. 4). Further, while $\mathrm{NO}_{3}-\mathrm{N}$ and $\mathrm{NH}_{4}-\mathrm{N}$ illustrated significant decline, $\mathrm{NO}_{2}-\mathrm{N}$ showed an insignificant decrease in fortnight concentrations at Garudeshwar (Fig. 4).

While plotting the cumulative curve of fortnight water flux, we found that upstream and downstream discharge ratios are smaller than 1, indicating that downstream discharge is higher than upstream throughout the study period. It means that at a fortnight scale, there was no noticeable reduction in water discharge. In the case of fortnight DIN, DIP, and DSi, fluxes ratios of upstream and downstream are higher than one, signifying that downstream nutrient discharge is lesser than upstream throughout the study period (Fig. 5). Note that DSi and DIP ratios of cumulative fluxes remain in the same order. However, for the DIN/NO $\mathrm{N}_{3}-\mathrm{N}$, upstream versus downstream ratios changed by order of magnitude, implying DIN's relatively substantial depletion. We observed that different DIN species responded differently to increased residence time with $\mathrm{NO}_{3}-\mathrm{N}$ retention was most astonishing, followed by $\mathrm{NO}_{2}-\mathrm{N}$ and $\mathrm{NH}_{4}-\mathrm{N}$.

We found that during the period of 11 water yearsin terms of mean concentrations-flow adjusted DSi reduced from 470 (at Rajghat) to $214 \mu \mathrm{M}$ (at Garudeshwar), 

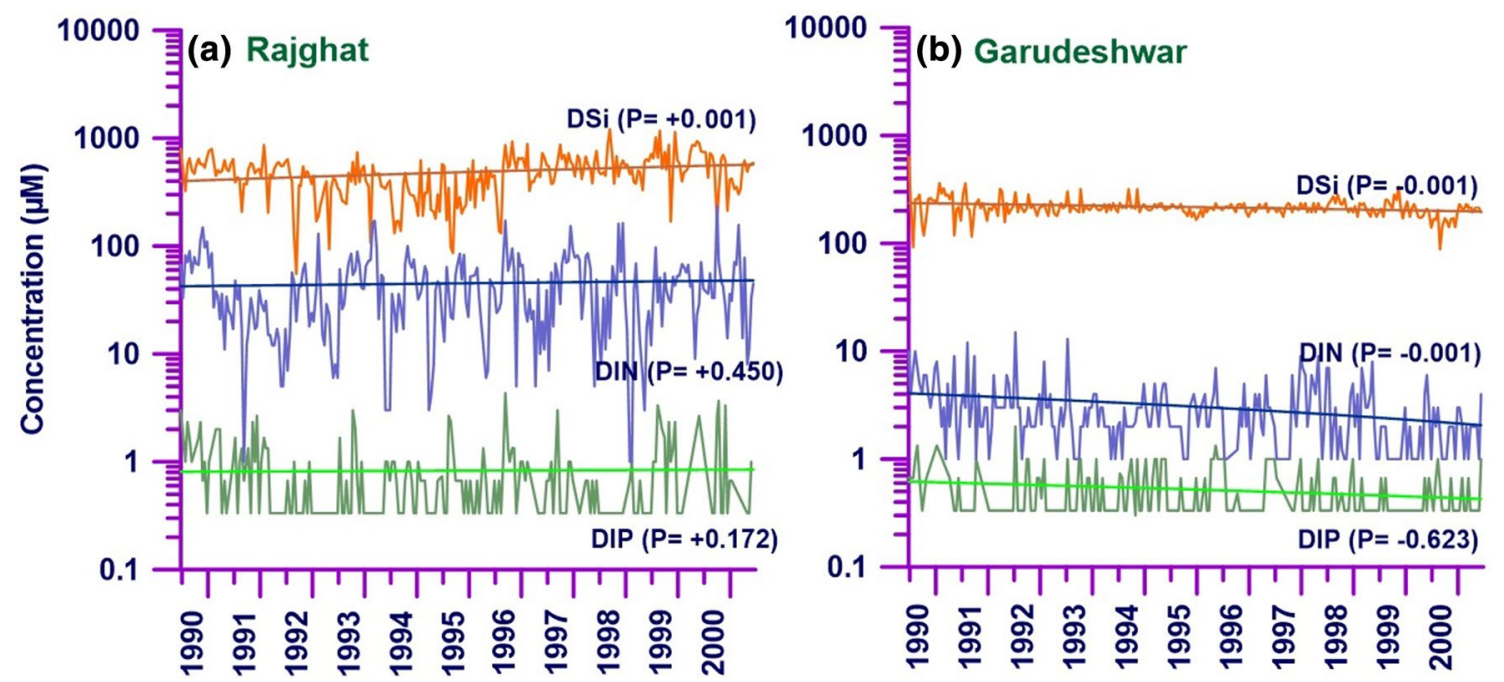

Fig. 4 Time series of fortnight nutrients concentrations ( $\mu \mathrm{M}$; at log scale) during 11 water years at two successive locations: upstream and downstream, of the SS dam. In contrary to panel a, trends in fortnight nutrient concentrations in panel $b$ show negative trends and are remarkably lower than upstream inflow. Mean concentrations of DIP, DIN, and DSi and its standard deviations for all sam-

DIN from 43 to $1.5 \mu \mathrm{M}$, and DIP from 0.84 to $0.38 \mu \mathrm{M}$. The mean annual inflow of DSi, DIN, and DIP was $9.91 \times 10^{5}$ tons, $0.96 \times 10^{5}$ tons, and $0.0285 \times 10^{5}$ tons at Rajghat. However, these dissolved nutrients' outflow was reduced to $4.48 \times 10^{5}$ tons, $0.040 \times 10^{5}$ tons, and $0.0134 \times 10^{5}$ tons at Garudeshwar, respectively. During 11 years, about $59.6 \times 10^{5}$ tons of DSi, $9.79 \times 10^{5}$ tons of DIN, and $0.167 \times 10^{5}$ tons of DIP were retained behind the dam. The nutrient retention in the SS reservoir corresponds to about $53 \%, 55 \%$, and $96 \%$ for the total flux of DIP, DSi, and DIN at the basin's outlet. During the water year 2000-2001, retentions were higher as about $75 \%$ flux of phosphate, $79 \%$ of the upstream flux of silica, and $99 \%$ flux of $N$ were retained. North et al. [54] recorded retention of $\mathrm{P}, \mathrm{N}$, and $\mathrm{Si}$ to be $60 \%, 40 \%$, and $30 \%$, respectively, for the Diefenbaker reservoir of the South Saskatchewan River in Canada.

\subsection{Biological consumption and change in nutrient ratio}

In the presence of adequate light and temperature, the availability of nutrients acts as limiting factors for phytoplankton's growth. In the coastal and marine environments, phytoplankton's growth tends to be N limited, while in freshwater ecosystems, phytoplankton tends to be $P$ limited [33]. Mean annual ratio Si:N:P at the Rajghat is about 800:45:1, which means that phytoplankton growth in the Narmada basin is P limited. We estimated that at an annual scale the SS reservoir retained $18.96 \times 10^{6} \mathrm{~mol}$ of DIP. If this amount is accounted for biological production ples of Rajghat are $0.81 \pm 0.75 \mu \mathrm{M}, 45 \pm 35 \mu \mathrm{M}$, and $485 \pm 198 \mu \mathrm{M}$, respectively. In contrast, the mean concentrations of DIP, TN, and DSi and its standard deviations for samples collected downstream of the SS dam at Garudeshwar are $0.52 \pm 0.29 \mu \mathrm{M}, 3.1 \pm 2.2 \mu \mathrm{M}$, and $217 \pm 46 \mu \mathrm{M}$, respectively

following the Redfield ratios [60], it will consume about $0.303 \times 10^{9} \mathrm{~mol}$ of DIN and a similar DSi amount. A significant portion of $0.303 \times 10^{9} \mathrm{~mol}$ of DIN, may be consumed during primary production. Thus, consumed DIN might be buried along with the suspended sediments or convert as dissolved organic nitrogen (DON). However, the overall amount of dissolved silica and inorganic $\mathrm{N}$ retained by the reservoir is about $15.10 \times 10^{9} \mathrm{~mol}$ year ${ }^{-1}$ and $1.13 \times 10^{9} \mathrm{~mol}$ year $^{-1}$. It raises questions about the remaining amounts of DSi and DIN's fate and the mechanisms that control the ecosystem's Si-N cycle. Harrison et al. [32] suggested that in the mid-1990s, inland lakes and reservoirs eliminated about $1,407 \times 10^{9} \mathrm{~mol}$ of DIN per year, globally, with reservoirs responsible for $33 \%$ of this. In a subsequent study, Beusen et al. [8] proposed that at the end of the twentieth century about $1,929 \times 10^{9}$ mol year $^{-1}$ of DIN were being eliminated in river systems, with $24 \%$ taking place in reservoirs.

It is well known that part of the DSi produced through weathering is used in the bio-geosphere in aquatic ecosystems by diatoms, sponges, chrysophytes, radiolarians, and silicoflagellates [11]. Diatoms take DSi as biogenic silica to construct their cell walls (frustules) and contribute about $25 \%$ of the world's entire net primary production [75]. Therefore, increased diatom population and subsequent sedimentation might be critical processes, utilizing silica in reservoirs. However, overall, DSi retention in the SS reservoir is significantly higher; hence, it cannot be explained by biological processes alone. Humborg et al. [34] observed that a reservoir with massive live 

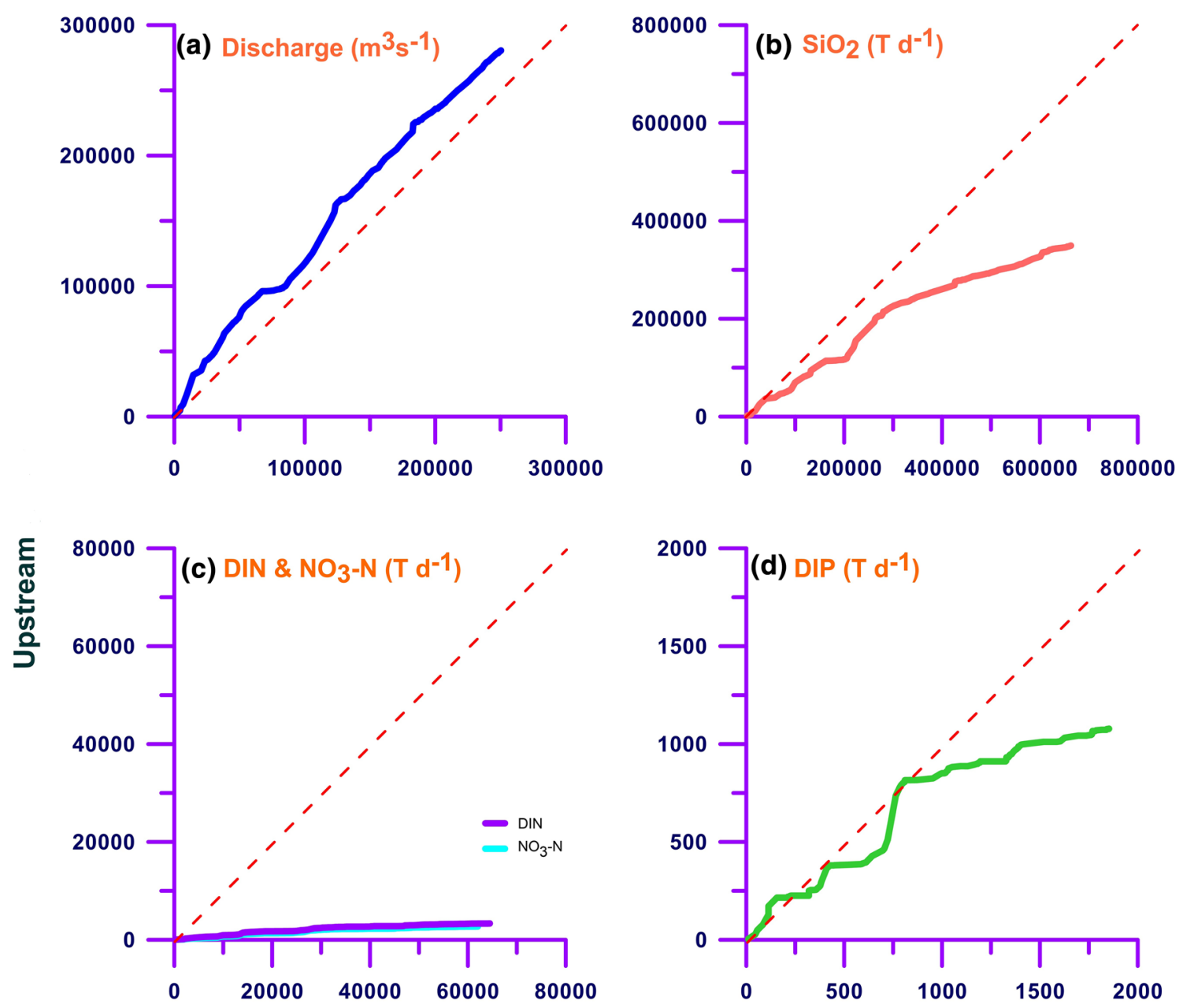

Downstream

Fig. 5 Variations in the cumulative fortnight water discharge, DSi, DIN/NO ${ }_{3}-\mathrm{N}$, and DIP fluxes at upstream (Rajghat) and downstream (Garudeshwar) locations. A hypothetical 1:1 line (dashed line) has been drawn for comparison. Note that fortnight water discharge at Garudeshwar was higher than that of Rajghat throughout the study period. On the contrary, the cumulative curves of DSi and DIP, DIN/ $\mathrm{NO}_{3}-\mathrm{N}$, reveal a remarkable decline in the fluxes. Mean concentra-

storage result in lower DSi concentration, showing higher silica retention efficiency. Turner et al. [70] suggested that there may be some non-biological mechanisms of silicate trapping in large reservoirs, perhaps through an organic complex.

Naqvi et al. [52] sampled the SS reservoir, observed the temperature and oxygen levels, and measured the concentrations of $\mathrm{NO}_{3}{ }^{-}, \mathrm{NO}_{2}{ }^{-}, \mathrm{NH}_{4}{ }^{+}, \mathrm{CH}_{4}$, and $\mathrm{N}_{2} \mathrm{O}$ for epilimnion and hypolimnion. So far, except for this one-time sampling in May 2013 by Naqvi et al. [52], no other research has been conducted to understand the mechanism and processes responsible for this significant retention of nutrients in the SS reservoir. Therefore, in the proceeding section, based on the data provided by Naqvi et al. [52] and tions of DIP, DIN, and DSi and its standard deviations for all samples of Rajghat are $0.81 \pm 0.75 \mu \mathrm{M}, 45 \pm 35 \mu \mathrm{M}$, and $485 \pm 198 \mu \mathrm{M}$, respectively. In comparison, the mean concentrations of DIP, TN, and DSi and its standard deviations for samples collected downstream of the SS dam at Garudeshwar are $0.52 \pm 0.29 \mu \mathrm{M}, 3.1 \pm 2.2 \mu \mathrm{M}$, and $217 \pm 46 \mu \mathrm{M}$, respectively. The number of fortnight samples for each location is 264 ( 24 each for 11 years)

published literature, we attempt to unravel the anticipated mechanism.

Contrary to silica, multiple sources and sinks make a terrestrial component of the $\mathrm{N}$ cycle more complicated. Though our understanding of the biogeochemical processes and $\mathrm{N}$ sinks in reservoirs is limited, growing interest in the denitrification potential of reservoirs and burial of organic matter guiding toward better documentation of these ecosystems. Denitrification and burial of organic matter below the active upper sediment layer permanently eliminate $\mathrm{N}$ from the aquatic system [2]. Saunders and Kalff [63] identified three broad components of $\mathrm{N}$ retention in reservoirs: uptake by vegetation, sedimentation, and denitrification, whereas hydrolysis and mineralization 
act reverse to it [2]. We have already shown that primary productivity may consume about $0.303 \times 10^{9} \mathrm{~mol}$ of DIN, which implies that annually through primary productivity in the epilimnion, about a $2.00 \times 10^{9} \mathrm{~mol}$ of atmospheric $\mathrm{CO}_{2}$ may have been translated into the organic matter. It is known that deep reservoirs stratify water into layers of different light and temperature, with the darkest and coldest near the bottom. The presence of stratified layers in the Indian reservoirs is confirmed by Narvenkar et al. [53], who sampled eight Indian reservoirs and observed strong thermal stratification during summer in all of these reservoirs. It means that most of the SS reservoir's primary productivity is restricted to the upper few meters of the water column. In the SS reservoir, water transparency is very much dependent on the monsoon inflow of sediment laden water. We found strong seasonality in fortnight surface turbidity data at Rajghat, with high turbid (up to 400 NTU) water mostly occur between June and October. Our observations are confirmed by Bardhan et al. [5], who reported significantly lower productivity during the monsoon period due to light-limited conditions in the Tillari reservoir of the Western Ghats region. Despite more significant nutrient loading, higher suspended sediment concentrations during monsoon season reduce light penetration. It may limit plankton growth and hence may slow down the biogenic removal of DSi and DIN. Light penetration range certainly improves during the non-monsoon season; however, plankton growth will be hampered by $\mathrm{P}$ limited environment.

Increased water retention time, promotes the uptake of $\mathrm{N}$ and $\mathrm{P}$ from the available pool of dissolved nutrients in the reservoirs. The SS reservoir has an annual average residence time of about 244 days. However, because of the reservoir's morphometric configuration, horizontal water movements except for monsoon season remain slow. Upwelling/reservoir surface water and atmosphere interface interactions may also supplement oxygen availability; however, it is only possible in the cases of shallow reservoirs. From meteorological data obtained from the CWC, it is estimated that at Rajghat, which is located in a relatively flat area, wind velocity varies between 2 and $12 \mathrm{~km} \mathrm{~h}^{-1}$ (annual mean $4.5 \mathrm{~km} \mathrm{~h}^{-1}$ ). The $\mathrm{SS}$ reservoir is relatively deep and has a vast stretch of the reservoir is surrounded by a continuous stretch $(110 \mathrm{~km})$ of hilly and forested terrain, which starts immediately downstream of Rajghat. Therefore, any large-scale turbulent mixing of reservoir waters and/or air-water interface is unlikely, restricting the loading of fresh oxygen to the anoxic water column. Bardhan et al. [5] observed that the water column of $50 \mathrm{~m}$ deep Tillari reservoir remains thermally stratified during spring and summer months until the onset of monsoon. Greater reservoir depths, rapid settling of particles, and morphometry may not allow any intense wind-induced mixing and restricts the recycling of P. With changing physiochemical conditions in the reservoir, an additional amount of $\mathrm{P}$ may come from dissolution and desorption of $\mathrm{P}$ attached with sediment particles and onto the clay minerals. Higher retention of DIN further skewed the relative availability of nutrients (Si:N:P ratios $=812: 75: 1$ ) in the reservoir, thus restraining the scope of all amounts of retained $\mathrm{N}$ and silica being consumed biologically. It implied that $P$ supply's natural mean seems not to be sufficient as an overall requirement of $P$ is at least 75 times higher. Therefore, it is assumed that the biogenic removal of DSi and DIN through primary productivity may not be an efficient process in the SS reservoir case.

Organic matter produced through photosynthetic carbon fixation becomes part of the reservoir ecosystem. It would be subsequently consumed by zooplankton and so on; however, autochthonous organic material will eventually settle at the bottom of the reservoir along with sediments transported by the river. Every year during flood season, rivers also transport a considerable amount of terrestrial organic matter (allochthonous), which eventually buries in the reservoir along with sediments. Gupta et al. [29] shown that $86 \%$ of the total sediment load transported downstream during major flood events ( $\geq 1$ MT day ${ }^{-1}$ ) being trapped by the SS reservoir. It means this type of sedimentation will bury most of the autochthonous and allochthonous organic matter. It becomes further critical as $55 \%$, and $34 \%$ of particulate organic matter in the Deccan Trap region originates from allochthonous litter/riparian and soil sources, respectively [59]. With the closing of a new dam, reservoir water inundates the surrounding vegetation/forests, thus adding a massive amount of standing organic matter beneath the water column. In the presence of oxygen, this organic matter will decompose to give rise to $\mathrm{CO}_{2}$. However, if the amount of organic matter to be decomposed is enormous, it will lead to a lack of oxygen in the system. Paerl et al. [56] observed that high dissolved organic carbon loadings from agricultural sources contribute to anoxia/hypoxia in coastal waters.

Similarly, depletion of oxygen may result in anoxia, in newly created reservoirs. Our assumptions are in accord with several previous studies on reservoirs. Indian reservoirs experience varying degrees of oxygen depletion in the hypolimnia, ranging from hypoxia to complete anoxia, in spring-summer [53]. According to them, anoxia dramatically affects the distribution of $\mathrm{N}$ species in the Indian reservoirs. The difference between the oxygen levels in the epilimnion (5.35-5.61 $\mathrm{mg} \mathrm{I}^{-1}$ ) and the hypolimnion (not detectable to $3.19 \mathrm{mg} \mathrm{I}^{-1}$ ) of the SS dam as reported by Naqvi et al. [52] strengthens our arguments. The current paradigm for artificial reservoirs hold that submergence of soils, associated vegetation, and forests under reservoir 
water result in decomposition of organic matter $[9,16$, $36,62]$ which, lead to high post-flood $\mathrm{CO}_{2}$ and $\mathrm{CH}_{4}$ emission $[1,20]$. The level of $\mathrm{CH}_{4}$ shows a significant increase in the hypolimnion $(0.037-92.0 \mu \mathrm{M})$ if compared to that of epilimnion $(0.06 \mu \mathrm{M})$ for the SS reservoir [52]. Similarly, the presence of $\mathrm{N}_{2} \mathrm{O}$ in the epilimnion (8.51-9.37 nM) and in the hypolimnion (4.24-14.46 $\mathrm{nM}$ ) is also reported by Naqvi et al. [52]. It is also well recorded that the initial high decomposition and emission rates tend to decline in the subsequent years after the first flooding $[67,69]$. In a study on reservoirs, Barros et al. [6] linked carbon emission to reservoir age, latitude, location biome, morphometric feature, and chemical status.

Seitzinger [64] suggested that denitrification is potentially an essential component of the $\mathrm{N}$ budget in aquatic ecosystems. Richards [61] mentioned that the transition from the 'oxic' to 'anoxic' conditions involves several significant biogeochemical changes. The first step of denitrification is the reduction of nitrate to nitrite. Later, nitrite either can be reduced to ammonia (dissimilatory nitrate reduction to ammonia) or sequentially transformed to nitric oxide, nitrous oxide, and nitrogen gas (conventional denitrification) [10]. The facultative bacteria switch over to nitrate ions, which are the next most abundant source of free energy for organic matter oxidation. Thus, nitrate is reduced to molecular $\mathrm{N}$ with nitrite, which accumulates in the water column, as one of several intermediates; this process, known as denitrification, is a significant component of the $\mathrm{N}$ cycle. Denitrification has vital geochemical significance since free $\mathrm{N}$ refluxed to the atmosphere makes up for the river's inputs alone, unlike the marine environment, where it is a combined input of atmosphere and rivers. A similar mechanism may also be true for the SS reservoir. Naqvi et al. [52] suggested a significant increase in $\mathrm{N}$ enrichment of the SS reservoir's bottom waters. The concentration of $\mathrm{NO}_{3}{ }^{-}(0.11-0.12$ to $4.67-42.89 \mu \mathrm{M})$, $\mathrm{NO}_{2}^{-}(0.02-0.03$ to $0.06-0.34 \mu \mathrm{M})$, and $\mathrm{NH}_{4}{ }^{+}(0.73-0.84$ to 0.34-1.55 $\mu \mathrm{M}$ ) increase from epilimnion to hypolimnion. Prevailing environmental variables such as nitrate supply, $\mathrm{pH}, \mathrm{DO}, \mathrm{DOC}$ and $\mathrm{P}$, temperature, light, water residence time, and the submerged vegetation might influence the denitrification process [25]. Through an experimental study on $\mathrm{N}$ retention capacity in different types of wetlands in agricultural areas, Jansson et al. [39] demonstrated that the $\mathrm{N}$ removal in wetlands depends mainly on denitrification. The $\mathrm{N}$, together with $\mathrm{P}$, is the most production stimulating nutrient and acts as a catalyst for the decomposition of organic material in sediment [39]. Now it is well recognized that denitrification, the bacterial reduction of nitrate to $\mathrm{N}_{2}$ gas via nitrite, is a crucial $\mathrm{N}$ sink in aquatic environments and denitrification is favored in sediments with hypoxic or anoxic bottom waters, particularly in systems with abundant organic carbon and nitrate
$[58,65]$. Denitrification rates in the water column can be affected by nitrate availability, water temperature, organic carbon content, and dissolved oxygen [7]. Globally, reservoirs emit 3.7 $\mathrm{Tg} \mathrm{N}$ year ${ }^{-1}$ as $\mathrm{N}_{2}$ gas via denitrification, bury $1.54 \mathrm{Tg} \mathrm{N}_{\text {year }}{ }^{-1}$ in sediments and nitrification fix $0.98 \mathrm{Tg} \mathrm{N}$ year $^{-1}$ [47] and reference therein).

It means that with relatively long residence time, reservoirs offer a better opportunity for particle settling and nutrient processing and thus may serve as extensive denitrification and $\mathrm{N}$ burial hot spots. Denitrification of excess $\mathrm{N}$ species-in the absence of oxygen - could be such a method that may explain the extraordinary loss of DIN $\left(1.13 \times 10^{9} \mathrm{~mol} \mathrm{year}^{-1}\right)$ in the SS reservoir. We estimated that between 1990-1991 and 2000-2001, about 235 MT of suspended sediments were deposited in the reservoir, translating to a deposition rate of $320 \mathrm{~mm}_{\text {year }}{ }^{-1}$. It is assumed that a significant portion of particulate organic matter transported by the river into the reservoirs is being deposited along with sediments. Furthermore, $134 \mathrm{~km}^{2}$ and $113 \mathrm{~km}^{2}$ of reservoir land come under forest and cultivable land category, respectively. The mountainous stretch along the reservoir is, notably well forested. Burial of organic matter and inundation of farmland and forests may enhance organic matter decomposition and result in oxygen depletion from the water column during initial years of dam closer. The decline in reservoir levels during summer months will allow new vegetation to grow, and thus, seasonal fluctuation in reservoir level may also result in increased decomposition. The SS reservoir with an average width of $1.77 \mathrm{~km}$ (maximum width $16 \mathrm{~km}$ ) and a length of $214 \mathrm{~km}$ is a long shaped reservoir and has around $25 \mathrm{~m}$ tail water level. Fortnight surface water temperature at Rajghat varies from 15 to $33^{\circ} \mathrm{C}$ (long-term mean $25^{\circ} \mathrm{C}$ ). The mean annual nitrate concentration is about $43 \mu \mathrm{M}$ (range 15-72 $\mu \mathrm{M}$ ). Thus, the SS dam satisfies all prerequisites to be an $\mathrm{N}$ removal hot spot, as Beauchamp et al. [7] suggested.

The annual denitrification rate in the SS reservoir during the study period, varying between 17,800 and $189,500 \mathrm{~kg} \mathrm{~N} \mathrm{~km}^{-2}$ with an average of $80,000 \mathrm{~kg} \mathrm{~N} \mathrm{~km}^{-2}$. These estimations are for about $250 \mathrm{~km}^{2}$ reservoir area located between Rajghat and the dam site. Pina-Ochoa and Alvarez-Cobelas [58] measured denitrification rates in several lakes individually, which varied between 181 and $38,263 \mathrm{~kg} \mathrm{~N} \mathrm{~km}^{-2}$ year $^{-1}$. Subsequent studies (i.e., $[15,26,30,42])$ reported denitrification rates to vary from 10 to $108,000 \mathrm{~kg} \mathrm{~N} \mathrm{~km}^{-2}$ year $^{-1}$. In a global-scale study, Seitzinger et al. [65] estimated that denitrification rates in human-made reservoirs are about $11,000 \mathrm{~kg} \mathrm{~N} \mathrm{~km}^{-2}$ year $^{-1}$. However, later based on the NiRReLa model, Harrison et al. [32] estimated that the area-specific rate of $\mathrm{N}$ removal by lentic systems globally is about $4805 \mathrm{~kg} \mathrm{~N} \mathrm{~km}^{-2}$ year $^{-1}$. So far, it means that reported denitrification rates in different freshwater systems across the globe vary by order of 
two. It implied that a portion of DIN is utilized in primary production, whereas the rest is lost to the atmosphere through denitrification in the anoxic water column. It is inferred that the SS reservoir's denitrification rates may be extraordinarily higher than most of these global and individual lake scale estimates. Harrison et al. [32] also shown that $\mathrm{N}$ removal behind dams varies between 0 and $99 \%$ and 0.04 to $68.5 \%$ in reservoirs located in temperate and tropical regions, respectively. In the case of a tropical SS reservoir, the mean annual $\mathrm{N}$ removal is about $96 \%$ (range: 86 to $99 \%$ ) of upstream loading. It seems not surprising as for the reservoirs included by Harrison et al. [32], the height of dams varies from 2 to $55 \mathrm{~m}$, with residence time from 1 day to 12.6 years. Maavara et al. [48] calculated that at a global scale nitrification and denitrification processes result in $27 \%$ and $22 \%$ of terrestrial $\mathrm{N}$ inputs losses, respectively, in the reservoirs. According to Maavara et al. [48], the $\mathrm{N}$ losses in the reservoir by nitrification and denitrification processes is much higher than that in free flowing rivers ( $<0.5 \%$ collectively).

\subsection{Nutrient flux to the coastal Arabian Sea}

Located in the tropical region, the Arabian Sea receives inputs from rivers draining the Indian subcontinent, the middle east region of Asia, and Africa's eastern coast. The Arabian Sea has long been known to experience an intense depletion of dissolved oxygen at intermediate depths [51]. The Arabian Sea experiences extremes in atmospheric, forcing a seasonal reversal in monsoon patterns, which lead to the highest seasonal variability of biological productivity observed in any ocean basin [4]. Despite $\mathrm{N}$ limited conditions, coastal primary productivity along the north and west coast is higher due to riverine inputs of nutrients, particularly DIN. Therefore, the continuous supply of DIN is crucial in sustaining primary productivity and coastal ecosystem. Dewani et al. [17] estimated that during 2 years of the study period, the Indus River delivered 0.420 MT and 0.496 MT of N for the years 1994 and 1995, respectively, to the Arabian Sea. Singh and Ramesh [66] estimated that the N inputs form Indian rivers to the Arabian Sea, which vary from 0.7 to 3 MT N year ${ }^{-1}$. Krishna et al. [43] suggested that the Arabian Sea receives about 100 MT of DIN annually and proposed that it is principally due to the polluted Narmada and Tapti rivers in the northwest Arabian Sea. However, it seems to be incorrect as presently the Narmada basin delivers about 0.0044 MT DIN. Even before the SS dam, the annual DIN flux was about 0.0964 MT. These rivers, mainly flowing through the Indian subcontinent have been regulated by hundreds of large and several megadams, and any decline in the supply of DIN will result in reduced primary productivity. This is also important to note that most of the large rivers discharging to the Arabian Sea (i.e., Indus, Narmada, Tapti, etc.) experiencing a decline in the fluxes of water, suspended sediments and dissolved constituents; hence, the west-flowing coastal rivers became the major source of water and elemental fluxes to the Arabian Sea.

Based on long-term data (between 1979 and 1992) of water and nutrient discharge from the Danube River to the Black Sea, Humborg et al. [35] have shown downstream DSi concentrations are reduced by more than $60 \%$ and suggested that damming of the Danube has been instrumental in causing changes in $\mathrm{Si} / \mathrm{N}$ ratios. This study by Humborg et al. [35] provided first-ever evidence of consequential dramatic shifts in species composition from diatoms to non-siliceous coccolithophores and flagellates. However, despite a significant decline in the DSi transport by the Narmada River, there may not be a dramatic shift in DSi concentrations in coastal waters, given the silica concentration in the Narmada River is still comparable to the global mean values. Similarly, the $\mathrm{P}$ is also not a limiting nutrient in the Arabian Sea. Hence, the decline in DIN inputs might limit the biological production in the Arabian Sea's coastal water.

\subsection{Implications for coastal productivity}

We estimate that due to the decline in the DIN fluxes from the Narmada River to the coastal system by $1.13 \times 10^{9} \mathrm{~mol}_{\text {year }}{ }^{-1}$, it will reduce the atmospheric $\mathrm{CO}_{2}$ fixation by $7.46 \times 10^{9} \mathrm{~mol} \mathrm{year}^{-1}$. Gupta et al. [28] estimated that silicate weathering of basaltic rocks in the Narmada basin consume about $32 \times 10^{9} \mathrm{~mol} \mathrm{C} \mathrm{year}^{-1}$. Note that the potential amount of $\mathrm{CO}_{2}$ that may have been fixed through primary productivity in the coastal environment, if all DIN may have delivered to the Arabian $\mathrm{Sea}$, is comparable to the amount of $\mathrm{CO}_{2}$ being fixed via silicate weathering Narmada basin. We further estimate that about $166 \times 10^{9} \mathrm{~mol}$ of DIN may have lost during 11 years of the study period through denitrification and burial, which may otherwise be used by phytoplankton to fix about $82 \times 10^{9} \mathrm{~mol}$ of atmospheric $\mathrm{CO}_{2}$. Studies lead by SWA Naqvi and his research group $[5,52,53]$, have documented the production of $\mathrm{CH}_{4}$ and $\mathrm{N}_{2} \mathrm{O}$ in the Indian reservoirs. However, the volume of greenhouse gas produced during organic matter decomposition $\left(\mathrm{CO}_{2}\right.$ and $\left.\mathrm{CH}_{4}\right)$ and through denitrification $\left(\mathrm{N}_{2} \mathrm{O}\right)$ remains undocumented for the SS reservoir. Our results are inline with [47], who proposed that dam-driven changes to nutrient stoichiometry operate in conjunction with other anthropogenic influences and modify ecosystem structure and functions. 


\section{Conclusion}

This study demonstrates the retention of dissolved inorganic nutrients in a large tropical reservoir located in Central India. Changes in fortnight nutrients outflow over 10 years, from two monitoring stations situated around $200 \mathrm{~km}$ apart on the Narmada River observed. No significant change in nutrient concentration was observed at the upstream monitoring station; however, at the station downstream to the dam, a significant decline in dissolved nitrate, nitrite, phosphate, and silica was observed. This significant decline in concentration and fluxes indicates the retention of these nutrients behind the dam. Most of the nitrate and more than half of silica and phosphate were removed between two monitoring stations. A significant decline in suspended sediment load also supports the role of the SS reservoir in material sequestration. Global studies suggest primary production in the photic zone and denitrification in the aphotic zone, to be the primary process for the changes in the fate of $\mathrm{N}$. A recent study on the nitrogen loss from the Indian reservoirs confirms seasonal stratification in the Indian reservoirs and seasonal loss to $\mathrm{N}_{2}$ in anoxic hypolimnia. This study reported the accumulation of $\mathrm{CH}_{4}$ in the anoxic layers and production of $\mathrm{N}_{2} \mathrm{O}$, suggesting a widespread coupling between methanotrophy and denitrification. The obtained results and the current study's proposed mechanism are similar to existing global and Indian studies. The SS reservoir experiences a high sedimentation rate and results in the settling of autochthonous and allochthonous organic matter. Therefore, the SS reservoir is an excellent site for investigating $\mathrm{C} / \mathrm{N}$ isotopic signatures of the deposited organic matter, and future studies might relevel additional insight into the exact processes. This study suggests that a decline in nutrient supply, particularly the $\mathrm{N}$ species, will affect the primary productivity and thus the carbon fixation in the coast Arabian Sea. Hence, regular monitoring of the large reservoirs to transport carbon and nutrients should be made compulsory in the Environmental Impact Assessment reports.

Acknowledgements HG thanks the University Grants Commission, India, for the faculty position under Faculty Recharge Programme. KKR (IF150795), MC (IF160995), and GVK (IF10993) are grateful to the DST-Inspire Fellowship Program, India, for providing financial support. We are thankful to Narmada Basin Organization, Bhopal Central Water Commission India, for providing the fortnight water quality. Databases accessible online on the Central Water Commission and WRIS India portals were much helpful in carrying out this study. We are thankful to the anonymous reviewers and the editor for review and useful suggestions on this manuscript's earlier version.

\section{Compliance with ethical standards}

Conflict of interest All authors declare that they have no conflict of interest.

Open Access This article is licensed under a Creative Commons Attribution 4.0 International License, which permits use, sharing, adaptation, distribution and reproduction in any medium or format, as long as you give appropriate credit to the original author(s) and the source, provide a link to the Creative Commons licence, and indicate if changes were made. The images or other third party material in this article are included in the article's Creative Commons licence, unless indicated otherwise in a credit line to the material. If material is not included in the article's Creative Commons licence and your intended use is not permitted by statutory regulation or exceeds the permitted use, you will need to obtain permission directly from the copyright holder. To view a copy of this licence, visit http://creativecommons .org/licenses/by/4.0/.

\section{References}

1. Abril G, Parize M, Pérez MA, Filizola N (2013) Wood decomposition in Amazonian hydropower reservoirs: an additional source of greenhouse gases. J S Am Earth Sci 44:104-107

2. Akbarzadeh Z, Maavara T, Slowinski S, Van Cappellen P (2019) Effects of damming on river nitrogen fluxes: a global analysis. Global Biogeochem Cycles 33(11):1339-1357

3. Anonymous (2012) Report of the working group on fertilizer industry for the twelfth plan (2012-2013 to 2016-2017). Government of India Ministry of Chemicals and Fertilizers Department of Fertilizers, New Delhi

4. Bange HW, Rixen $T$, Johansen $A$, Siefert $R$, Ramesh R, Ittekkot $V$ et al (2000) A revised nitrogen budget for the Arabian Sea. Global Biogeochem Cycles 14(4):1283-1297

5. Bardhan P, Naqvi SWA, Karapurkar SG, Shenoy DM, Kurian S, Naik H (2017) Isotopic composition of nitrate and particulate organic matter in a pristine dam reservoir of western India: implications for biogeochemical processes. Biogeosciences 14:769-779

6. Barros N, Cole JJ, Tranvik LJ, Prairie YT, Bastviken D, Huszar VL et al (2011) Carbon emission from hydroelectric reservoirs linked to reservoir age and latitude. Nat Geosci 4(9):593

7. Beauchamp E, Trevors J, Paul J (1989) Carbon sources for bacterial denitrification. In: Advances in soil science. Springer, Berlin, pp 113-142

8. Beusen A, Bouwman A, Van Beek LP, Mogollon J, Middelburg JJ (2016) Global riverine $N$ and $P$ transport to ocean increased during the 20th century despite increased retention along the aquatic continuum. Biogeosciences 13(8):2441-2451

9. Bodaly R, Beaty KG, Hendzel LH, Majewski AR, Paterson MJ, Rolfhus KR, et al (2004) Peer reviewed: experimenting with hydroelectric reservoirs. ACS Publications

10. Chen X, Yang L, Xiao L, Miao A, Xi B (2012) Nitrogen removal by denitrification during cyanobacterial bloom in Lake Taihu. J Freshw Ecol 27(2):243-258

11. Conley DJ, Schelske CL, Stoermer EF (1993) Modification of the biogeochemical cycle of silica with eutrophication. Marine Ecology Progress Series, pp 179-192

12. CWC (2020) http://cwc.gov.in/sites/default/files/water-qualityactivities-cwc.pdf 
13. CWC-NBO (2000-01) Water Quality Data Book of Narmada Basin (2000-01), Narmada Basin Organisation, Central Water Commission, Bhopal

14. Dagg M, Benner R, Lohrenz S, Lawrence D (2004) Transformation of dissolved and particulate materials on continental shelves influenced by large rivers: plume processes. Cont Shelf Res 24(7-8):833-858

15. David MB, Wall LG, Royer TV, Tank JL (2006) Denitrification and the nitrogen budget of a reservoir in an agricultural landscape. Ecol Appl 16(6):2177-2190

16. Deemer BR, Harrison JA, Li S, Beaulieu JJ, DelSontro T, Barros $N$ et al (2016) Greenhouse gas emissions from reservoir water surfaces: a new global synthesis. Bioscience 66(11):949-964

17. Dewani V, Ansarj I, Khuhawar M (2000) Evaluation and transport of nitrogen and I phosphorus by river Indus at Kotri Barrage. Jour Chcrn Soc Pair 22(2):104-110

18. Downing J, Prairie Y, Cole J, Duarte C, Tranvik L, Striegl R et al (2006) The global abundance and size distribution of lakes, ponds, and impoundments. Limnol Oceanogr 51(5):2388-2397

19. Falkowski PG (1997) Evolution of the nitrogen cycle and its influence on the biological sequestration of $\mathrm{CO}_{2}$ in the ocean. Nature 387(6630):272-275

20. Fearnside PM (2016) Greenhouse gas emissions from hydroelectric dams in tropical forests. In: Alternative energy and shale gas encyclopedia, pp 426-436

21. Friedl G, Teodoru C, Wehrli B (2004) Is the iron gate I reservoir on the Danube River a sink for dissolved silica? Biogeochemistry 68(1):21-32

22. Galloway JN, Dentener FJ, Capone DG, Boyer EW, Howarth RW, Seitzinger SP et al (2004) Nitrogen cycles: past, present, and future. Biogeochemistry 70(2):153-226

23. Ganeshram RS, Pedersen TF, Calvert S, François R (2002) Reduced nitrogen fixation in the glacial ocean inferred from changes in marine nitrogen and phosphorus inventories. Nature 415(6868):156-159

24. Garnier J, Leporcq B, Sanchez N, Philippon X (1999) Biogeochemical budgets in three large reservoirs of the Seine basin (Marne, Seine \& Aube reservoirs). Biogeochemistry 47:1 19-146

25. Golterman HL (2004) Sediment and the phosphate cycle: part 2: release processes. In: The chemistry of phosphate and nitrogen compounds in sediments, pp 97-133

26. Grantz EM, Kogo A, Scott JT (2012) Partitioning whole-lake denitrification using in situ dinitrogen gas accumulation and intact sediment core experiments. Limnol Oceanogr 57(4):925-935

27. Gupta H, Chakrapani GJ (2005) Temporal and spatial variations in water flow and sediment load in Narmada River Basin, India: natural and man-made factors. Environ Geol 48(4-5):579-589. https://doi.org/10.1007/s00254-005-1314-2

28. Gupta H, Chakrapani GJ (2007) Temporal and spatial variations in water flow and sediment load in the Narmada river. Curr Sci 92(5):679-684

29. Gupta H, Chakrapani GJ, Selvaraj K, Kao SJ (2011) The fluvial geochemistry, contributions of silicate, carbonate and salinealkaline components to chemical weathering flux and controlling parameters: Narmada River (Deccan Traps) India. Geochim Cosmochim Acta 75(3):800-824

30. Gupta H, Kao S-J, Dai M (2012) The role of mega dams in reducing sediment fluxes: a case study of large Asian rivers. J Hydrol 464:447-458. https://doi.org/10.1016/j.jhydrol.2012.07.038

31. Han H, Lu X, Burger DF, Joshi UM, Zhang L (2014) Nitrogen dynamics at the sediment-water interface in a tropical reservoir. Ecol Eng 73:146-153

32. Hansen E, Chan KS, Jones CS, Schilling K (2016) Assessing the relative importance of nitrogen-retention processes in a large reservoir using time-series modeling. J Agric Biol Environ Stat 21(1):152-169

33. Harrison JA, Maranger RJ, Alexander RB, Giblin AE, Jacinthe P-A, Mayorga E et al (2009) The regional and global significance of nitrogen removal in lakes and reservoirs. Biogeochemistry 93(1-2):143-157

34. Hecky R, Kilham P (1988). Nutrient limitation of phytoplankton in freshwater and marine environments: a review of recent evidence on the effects of enrichment. Limnol Oceanogr 33(4 Part2):796-822

35. Humborg C, Blomqvist S, Avsan E, Bergensund Y, Smedberg E, Brink J, et al (2002) Hydrological alterations with river damming in northern Sweden: implications for weathering and river biogeochemistry. Glob Biogeochem Cycles 16(3):12-1-12-13

36. Humborg C, Ittekkot V, Cociasu Bodungen AB (1997) Effect of Danube River dam on Black Sea biogeochemistry and ecosystem structure. Nature 386(6623):385

37. Huttunen JT, Väisänen TS, Hellsten SK, Heikkinen $M$, Nykänen $\mathrm{H}$, Jungner $\mathrm{H}$, et al (2002) Fluxes of $\mathrm{CH}_{4}, \mathrm{CO}_{2}$, and $\mathrm{N}_{2} \mathrm{O}$ in hydroelectric reservoirs Lokka and Porttipahta in the northern boreal zone in Finland. Glob Biogeochem Cycles 16(1):3-1-3-17

38. ICOLD (2016) International Commission on Large Dams. www. icoldcigb.org/GB/World_register/general_synthesis.asp

39. Jain SK, Nayak PC, Singh Y, Chandniha SK (2017) Trends in rainfall and peak flows for some river basins in India. Curr Sci 112(8):1712-1726

40. Jansson M, Andersson R, Berggren H, Leonardson L (1994) Wetlands and lakes as nitrogen traps. Ambio 23:320-325

41. Kaushik $A$ (2006) Perspectives in environmental studies. New Age International, New Delhi

42. Kelly VJ (2001) Influence of reservoirs on solute transport: a regional-scale approach. Hydrol Process 15(7):1227-1249

43. Koszelnik P, Tomaszek JA, Gruca-Rokosz R (2007) The significance of denitrification in relation to external loading and nitrogen retention in a mountain reservoir. Mar Freshw Res 58(9):818-826

44. Krishna MS, Prasad MHK, Rao DB, Viswanadham R, Sarma VVSS, Reddy NPC (2016) Export of dissolved inorganic nutrients to the northern Indian Ocean from the Indian monsoonal rivers during discharge period. Geochim Cosmochim Acta 172:430-443

45. Leavitt PR, Brock CS, Ebel C, Patoine A (2006) Landscape-scale effects of urban nitrogen on a chain of freshwater lakes in central North America. Limnol Oceanogr 51(5):2262-2277

46. Liu Y, Deng B, Du J, Zhang G, Hou L (2019) Nutrient burial and environmental changes in the Yangtze Delta in response to recent river basin human activities. Environ Pollut 249:225-235

47. Maavara T, Akbarzadeh Z, Van Cappellen P (2020a) Global damdriven changes to riverine N:P:Si Ratios delivered to the coastal ocean. Geophys Res Lett 47(15):e2020GL088288

48. Maavara T, Chen Q, Van Meter K, Brown LE, Zhang J, Ni J, Zarfl C (2020) River dam impacts on biogeochemical cycling. Nat Rev Earth Environ 1:103-116

49. Maavara T, Lauerwald R, Laruelle GG, Akbarzadeh Z, Bouskill NJ, Van Cappellen P, Regnier P (2019) Nitrous oxide emissions from inland waters: are IPCC estimates too high? Glob Change Biol 25(2):473-488

50. Maavara T, Parsons CT, Ridenour C, Stojanovic S, Dürr HH, Powley HR et al (2015) Global phosphorus retention by river damming. Proc Natl Acad Sci 112(51):15603-15608

51. Meybeck M (2003) Global analysis of river systems: from Earth system controls to Anthropocene syndromes. Philos Trans R Soc Lond B Biol Sci 358(1440):1935-1955

52. Naqvi $S$ (1994) Denitrification processes in the Arabian Sea. Proc Indian Acad Sci Earth Planet Sci 103(2):279-300 
53. Naqvi SWA, Lam P, Narvenkar G, Sarkar A, Naik H, Pratihary A, Shenoy DM, Gauns M, Kurian S, Damare S, Duret M (2018) Methane stimulates massive nitrogen loss from freshwater reservoirs in India. Nat Commun 9(1):1-10

54. Narvenkar G, Naqvi SWA, Kurian S, Shenoy DM, Pratihary AK, Naik H, Patil S, Sarkar A, Gauns M (2013) Dissolved methane in Indian freshwater reservoirs. Environ Monit Assess 185(8):6989-6999

55. North R, Davies JM, Doig L, Hudson J, Lindenschmidt KE (2015) Characterization and dynamics of a large multi-purpose prairie reservoir: Lake Diefenbaker, Saskatchewan Canada. J Great Lakes Res 41(Suppl 2):1-163

56. NRLD (2019) http://cwc.gov.in/national-register-large-dams

57. Paerl HW, Pinckney JL, Fear JM, Peierls BL (1998) Ecosystem responses to internal and watershed organic matter loading: consequences for hypoxia in the eutrophying Neuse River Estuary, North Carolina, USA. Marine Ecology Progress Series, pp $17-25$

58. Patoine A, Graham MD, Leavitt PR (2006) Spatial variation of nitrogen fixation in lakes of the northern Great Plains. Limnol Oceanogr 51(4):1665-1677

59. Pina-Ochoa E, Alvarez-Cobelas M (2006) Denitrification in aquatic environments: a cross-system analysis. Biogeochemistry 81(1):111-130

60. Reddy SKK, Gupta H, Badimela U, Reddy DV, Kurakalva RM, Kumar D (2021) Export of particulate organic carbon by the mountainous tropical rivers of Western Ghats, India: variations and controls. Sci Total Environ 751:142115. https://doi. org/10.1016/j.scitotenv.2020.142115

61. Redfield AC (1934) On the proportions of organic derivatives in sea water and their relation to the composition of plankton. James Johnstone memorial volume, pp 176-192

62. Richards FA (1965) Anoxic basins and fjords. Academic Press, London

63. Rudd JW, Hecky R, Harris R, Kelly C (1993) Are hydroelectric reservoirs significant sources of greenhouse gases. Ambio 22(4):246-248

64. Saunders D, Kalff J (2001) Nitrogen retention in wetlands, lakes and rivers. Hydrobiologia 443(1):205-212

65. Seitzinger $S$ (1988) Denitrification in freshwater and coastal marine ecosystems: ecological and geochemical significance. Limnol Oceanogr 33(4part2):702-724

66. Seitzinger S, Harrison J, Böhlke J, Bouwman A, Lowrance R, Peterson $B$ et al (2006) Denitrification across landscapes and waterscapes: a synthesis. Ecol Appl 16(6):2064-2090
67. Singh A, Ramesh R (2011) Contribution of riverine dissolved inorganic nitrogen flux to new production in the coastal northern Indian Ocean: an assessment. Int J Oceanogr

68. St. Louis VL, Kelly CA, Duchemin É, Rudd JW, Rosenberg DM (2000) Reservoir Surfaces as Sources of Greenhouse Gases to the Atmosphere: A Global Estimate: reservoirs are sources of greenhouse gases to the atmosphere, and their surface areas have increased to the point where they should be included in global inventories of anthropogenic emissions of greenhouse gases. AIBS Bull 50 (9): 766-775

69. Teodoru C, Wehrli B (2005) Retention of sediments and nutrients in the Iron Gate I Reservoir on the Danube River. Biogeochemistry 76(3):539-565

70. Tremblay A (2005) Greenhouse gas emissions-fluxes and processes: hydroelectric reservoirs and natural environments. Springer, Berlin

71. Turner RE, Rabalais NN, Justic' D, Dortch Q (2003) Global patterns of dissolved N, P and $\mathrm{Si}$ in large rivers. Biogeochemistry 64(3):297-317

72. Van Cappellen P, Maavara T (2016) Rivers in the Anthropocene: global scale modifications of riverine nutrient fluxes by damming. Ecohydrol Hydrobiol 16(2):106-111

73. Wada Y, Reager JT, Chao BF, Wang J, Lo MH, Song C et al (2017) Recent changes in land water storage and its contribution to sea level variations. Surv Geophys 38(1):131-152

74. Walling DE (1997) The response of sediment yields to environmental change. Hum Impact Erosion Sediment 245:77-89

75. Walling DE (2008) The changing sediment loads of the world's rivers. Annals of Warsaw University of Life Sciences-SGGW. Land Reclamation, 39

76. Wentzky VC, Tittel J, Jäger CG, Rinke K (2018) Mechanisms preventing a decrease in phytoplankton biomass after phosphorus reductions in a German drinking water reservoir-results from more than 50 years of observation. Freshw Biol 63(9):1063-1076

77. Willén E (1991) Planktonic diatoms—an ecological review. Algol Stud 62(69):106

Publisher's Note Springer Nature remains neutral with regard to jurisdictional claims in published maps and institutional affiliations. 